\title{
SIMULATION-BASED LEARNING IN RELIGIOUS EDUCATION TO DEVELOP STUDENT EMPATHY ON PEACE EDUCATION
}

\author{
Aries Musnandar ${ }^{1}$ \\ ${ }^{1}$ Post-Graduate Islamic Education Program, Universitas Islam Raden Rahmat, Malang, \\ raries.m1@gmail.com
}

\begin{abstract}
This study proposes an effective learning model to increase the quality of students' empathy through simulation-based learning. The student's noble behavior as the objective religious subject in schools can be reached by fostering empathy. But, conservative teaching techniques such as lecturing, presentation, and one-way communication are used by most teachers. In contrast, the simulation based-learning model for religious education could involve the affective domain which is appropriate to be used for behavior change. Peace education in religious education subjects can be elaborated proportionally using simulation based-learning for developing the empathy of students as an important factor to have better peace education results. By using the qualitative method, the author conducted interviews, observation, and literature review for further analysis of this study. Research results confirmed that teachers who apply simulation-based learning as a suitable method to enhance empathy for elevated tolerant behavior of students which is in line with the peace education view.
\end{abstract}

Keywords: Simulation-Based Learning, Empathy, Peace Education, Religious Education

Abstrak. Penelitian ini mengusulkan model pembelajaran yang efektif untuk meningkatkan kualitas empati siswa melalui pembelajaran berbasis simulasi. Perilaku mulia siswa sebagai mata pelajaran agama yang objektif di sekolah dapat dicapai dengan menumbuhkan empati. Namun, teknik pengajaran konservatif seperti ceramah, presentasi, dan komunikasi satu arah digunakan oleh sebagian besar guru. Sebaliknya, model pembelajaran berbasis simulasi untuk pendidikan agama dapat melibatkan ranah afektif yang cocok digunakan untuk perubahan perilaku. Pendidikan perdamaian pada mata pelajaran Pendidikan Agama dapat dielaborasi secara proporsional dengan menggunakan pembelajaran berbasis simulasi untuk menumbuhkan empati siswa sebagai faktor penting untuk mendapatkan hasil pendidikan perdamaian yang lebih baik. Dengan menggunakan metode kualitatif, penulis melakukan wawancara, observasi dan studi pustaka untuk analisis lebih lanjut dari penelitian ini. Hasil penelitian menegaskan bahwa guru yang menerapkan pembelajaran berbasis simulasi sebagai 
metode yang sesuai untuk meningkatkan empati terhadap peningkatan perilaku toleran siswa yang sejalan dengan pandangan pendidikan perdamaian.

Kata Kunci: Pembelajaran Berbasis Simulasi, Empati, Pendidikan Perdamaian, Pendidikan Agama

\section{Introduction}

The Act of National Education System on number 20/2003 as contained in Chapter 2, article 3, describing national education goal for nourishing students' potential in the belief of God, loving obedience to the will of God, acquiring the good character, maintaining a healthy life, having highly educated and obtaining competent performance, creative person, self-directed, accountable and democrat citizen. ${ }^{1}$ Thence, education instills students with human values. Those values are indicators for becoming manusia seutuhnya (a good citizen and /or good man), as the goal of the nation's character building.

The education goals of the school curriculum derived from the national education aims which are to develop student's potentials and capability for becoming good people in hard and soft skills. The skills mentioned above can be classified into two categories, namely academic-hard skills (knowledgeable and competent) and non-academic-soft skills such as belief in God, loving obedience to the will of God, acquiring good character, maintaining a healthy life, having highly educated and obtaining competent performance, creative person, selfdirected, accountable and democrat citizen. ${ }^{2}$

Regrettably, in the field, there is a converse situation where the schools focus dominantly on academics-hard skills. The situation mostly occurs due to the controlling paradigm of teachers and stakeholders more closely to the academic orientation rather than personality development preferences. This because they feel awe with kind of intellectual capacity. In this context,

\footnotetext{
${ }^{1}$ Undang Undang Pendidikan Nasional No. 20 Tahun 2003, Chapter 2, Article 3

${ }^{2}$ ibid
} 
personality development is written as character education that must be implemented in schools.

Bullying, acts of anarchy, a street brawl, crime, juvenile delinquency, and other problematic student behaviors becoming usual phenomena in public for years in Indonesia. Regrettably, the increase in bad deeds such as intolerance, obtrude and violence from time to time are happening. To some extent, this is a worse situation in the educational outcome.

Practical teaching and learning process in Indonesian public schools largely still emphasizing the cognitive aspect. Teachers, principals, and school stakeholders mostly possess similar views on academic achievement and cognitive intelligence. Contrary, the spread public opinion available regarded that an excellent school is a school with the best rank in gaining intellectual or hard skills performance. ${ }^{3}$ Whereas, the potential of students' soft skills is neglected due to a lack of understanding of the advantages of soft skills.

Education is a crucial part of improving human quality. In SPN Act or Undang Undang Sistem Pendidikan National (SPN) no. 20 of 2003 chapter 2 section 3 stated that education is dedicated to betterment a character civilization, as well as of the nation's dignity. The National Education objective first and mainly is to arise student potentials for a man of piety with eminence and elevated character. The main goal of this national education act (UU SPN) of no. 20 the year 2003 has developed into more complete than previous Acts (year 1989 and 1954). However, the education results are still not achieved as expected. Yet, formal education on a massive scale cannot build moral sublime and the nation's virtuous character.

\section{Conceptual Framework}

Simulation-Based Learning: Concept and Practices

${ }^{3}$ Aries Musnandar, Pendidikan yang Mencerdaskan. (Yogyakarta: Naila Pustaka, 2013), P. 76- 
The various teaching methods used by teachers in the school are aimed to enable student learning. A method that can be used as a tool to educate students on personal skills is the simulation. In this study, the author proposes simulation-based learning in religious education as a method for students to enable to develop his/her empathy on peace education objectives. The concept is designed to help students to uphold and elevate personal empathy that needed to improve the quality of human interactions. This includes the expression of individual emotions which are utilized for either intra or interpersonal skills. Theoretically, the simulation method in this context "persons expect and be comprehensible of the behavior by activating cognitive mental processes that, if carried into action, may create similar behavior. For this reason, we contrive our mental states upon others".

Simulation is an experimental learning technique in which students are exposed to understanding and entering into another's feelings by undertaking some role play games. They play with different characters under the involvement of the teacher as a facilitator. Simulations are scenarios in learning and teaching activity where the students are involved in an imitation "world" determined by the teacher. They correspond to a reality within which students interact. The teacher manages the parameters of this "world" and utilizes it to attain the expected instructional objectives. Learners experience the reality of the simulation and collect meaning from it. Instructional simulation has the potency to pursue students in "deep learning", empower knowing as opposed to "surface learning" which requires memorization only.

\section{Empathy Conception and Peace Education}

The empathy of a person is trying to feel or to understand what the person feels in a certain condition experience from within the frame of reference. In other words, it is the capacity to place oneself in another's position. In the beginning, empathy can be recognized when an infant trying to do social contact and its surrounding environment. In this operational period, a baby up 
to 2 years old, getting realize of her surrounding object, tangible and she treated as tools of interaction. The baby's empathy appears when interacting with such a visible entity. ${ }^{4}$

The longer number of days the more empathy capabilities will be the higher caused by various human relations. During the adolescent period, people interact with numerous social activities that require various manners of adaptation. Once they involve social activities, they will need empathy. The presence of empathy is an important point for people in undertaking their life in a heterogeneous society.

Empathy is a built-in self-awareness domain. At first, empathy is wellrecognized when a baby attempts to conduct social contact with its surrounding environments interactively. A baby begins to realize someone else surrounding and interaction is part of her life to interacting and express her feeling to somebody else. This is a situation that as known as empathy or entering into another's feelings. The absence of empathy in the human being can be automatically caused behavior problems such as violent manners, anarchy acts, and other bad deeds including intolerance, obtrude, and hatred behaviors to others.

Furthermore, at 2,5 years old a kid starts to feel other feeling a bit deep by imitating on motoric function, for instance, he will also feel sad when looking at other kids in feeling sad. In the adolescent period, people face numerous social activities that need to use various adaptations. The role of empathy is critical in many living sectors such as business, industry, social politics, and including education. To maintain good rapport or human relations, we need to have good empathy. ${ }^{5}$

Students will be successful if they follow self-regulation (an ability to manage their emotions and impulses), hunt for self-motivation, have the empathy to sense others' feelings, and possess the talent to handle the emotions

\footnotetext{
${ }^{4}$ Aries Musnandar (2016). Op. Cit. Page 23-25

${ }^{5}$ Aries Musnandar (2016). Op. Cit. Page 20-21
} 
of others. ${ }^{6}$ There is no specific quality improvement program of empathy in schools despite a student personal empathy is an important aspect. The presence of empathy will bring them to positive attitudes such as respect, tolerance, and love for others. Religious education on Islamic subjects, in particular, should be embedded with empathy development.

Meanwhile, peace education, in general, is the process of inculcation values, getting knowledge, and elevating good character, noble behaviors, and personality to live in harmony, with others, and the surrounding environment. According to Tirsa Budiarti (2018) "peace education needs to be done in three stages: the awareness stage through the contemplative model and problemposing model; the stage of affection through the integration model and roleplaying model; then the implementation stage through the action-reflection model" which are implemented gradually based on pre-requisite program and activities. ${ }^{7}$ In this thing, the author regards also role-play and the actionreflection above as simulation-based learning model.

A teacher is a determinant component for improving the learning quality of an instructional system. Student learning ability and achievement in a school system cannot be separated from the role of a teacher. Maintaining class in a conducive atmosphere is necessary to make students active for better learning performance. A student is encouraged to get higher learning results. Specifically, when a teacher wants to have the empathy level of students to be high, then the teaching and learning process and activities should be conducted in an appropriate method.

In education concept and practice terms, changing behavior to the positive attitudes will cover the affective domain of the three well-known domains called Bloom's Taxonomy. It was created and popularized firstly by Benyamin Bloom in 1956 as a kind of classification of learning outcomes. Simulation with role play and student participation are good ways for gaining

${ }^{6}$ European Journal of Scientific Research, Vol. 91 No 1 November (2012): 69 C

${ }^{7}$ Tirsa Budiarti, "Model-Model Pendidikan Perdamaian Bagi Anak Dalam Konteks Gereja." Jurnal Jaffray, Vol. 16, No. 1, (2018): 67-69 
better education outcome. Therefore, religious education in schools ought to use such simulation method, particularly when teacher expects much on improving the students' affection side. The simulation-based learning concept in religious education to develop student empathy towards peace education can be elaborated as the picture below:

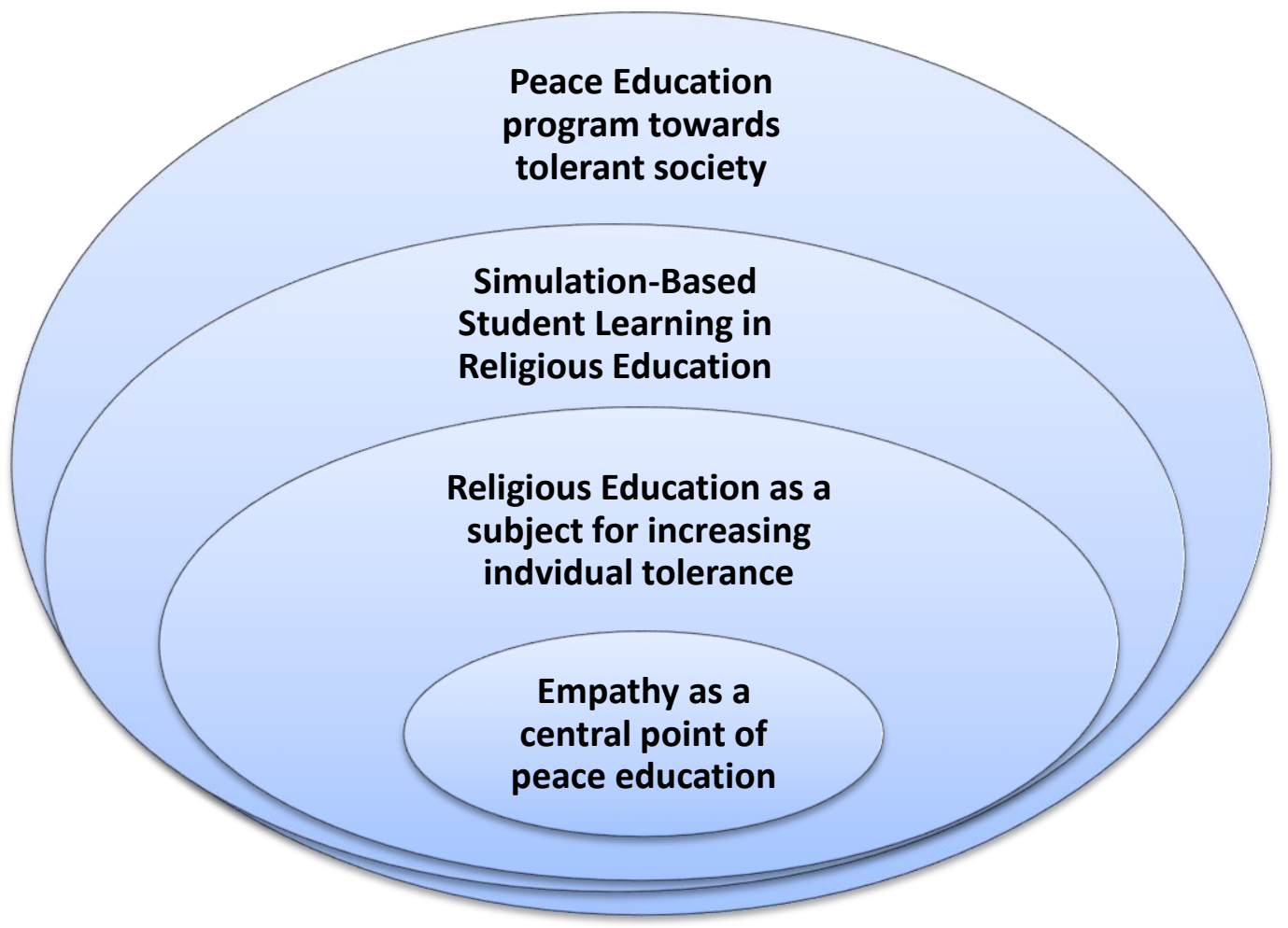

Picture 1.

\section{The Concept of Simulation-Based Learning in Religious Education for Peace Education}

\section{Focus of Study}

The phenomena as described above bring further consequences on the outcome and outputs of school. Graduates do not have a significant sense of empathy in their interaction caused less practicing altruistic behavior that should be implemented by the school as a behavior change system. The relevant teaching and learning method can elevate students' empathy but it is rarely 
applied by teachers. Theoretically, simulation-based learning is suitable to improve the sense of students' empathy in, especially behavior change-based subjects like religious education. In learning theory, a simulation method is used to replace concrete experience through managed experiences that replicate things of the concrete world. A simulation is the best learning method to apply for developing the empathy of students as it is a critical and main factor to have better peace education results.

Therefore, this paper will focus on and elucidate the use of the simulation method in religious education in Indonesian schools for shifting the student's behavior to have better personal attitudes. Good personal attitudes will bring students toward tolerance, respect, understanding, and entering another's feelings through suitable empathy. The questions to be answered upon this study among them are how do teachers usually deliver their teaching method for shaping the tolerant behavior of their students? How can teachers develop students' empathy and why simulation-based learning is needed for behavior change especially in the religious education context in Indonesia?

\section{Method}

In compiling this paper, the author uses qualitative method research or it is well known as a natural basis which data from previous and present phenomena are obtained through several resources such as interview, observation, and literature review to create propositions derived from research results, after analyzing the data. These data obtained in this study mostly derived from research results four years ago that were conducted by the author himself when finalizing his doctorate at the Maulana Malik Ibrahim Islamic University in Malang Indonesia.

\section{Result \& Discussion}

Religious Education and Peace Education 
Pendidikan Agama (Religious Education) in Indonesian schools consists of six official religions such as Islam, Christian, Catholic, Hinduism, Budha, and Confucius, as stipulated in Chapter 3 article 9 of the Government Regulation number 55 year $2007 .^{8}$ A long time before this regulation came into effect, the government imposed Islamic Religious education as a mandatory subject in public schools for Muslims. ${ }^{9}$

The content of such school subject covers mostly on relating to the spiritual ceremonies and ritual guidelines, such as prayers (sholat), alms (zakat), pilgrimage (hajj), estate of inheritance (fara'id), etc. Moreover, Islam is substantially not only limited to the implementation of rituals but, it also relates to sciences, human quality, justice, working professionally, create good deeds, and the ritual activities guidance. Islam teaches the glorious life in this world and hereafter.

Education activity has an important meaning in human life because the quality of human resources can be optimally improved and will form an advanced civilization up to the welfare of mankind through education. Countries that concern with the quality of education will prosper their people. Increasing prosperity allows people to have access to a good school education. The ultimate goal of education is to build a prosperous society or community in health and happiness.

However, the meaning of prosperity and happiness in the Islamic view is related to "hablumminallah wa hablumminannas". Al Attas stated a man of adab specifically and clearly as the person who is sincerely perceived and aware of his accountability towards the true God-Allah subhannahu wa ta'ala- La ilaha illallah. $\mathrm{He} / \mathrm{she}$ understands, fully obeys the order of the Almighty, and fulfills the obligations to him/herself and others in society with justice. The person constantly and always strives to improve every aspect of him/herself towards

${ }^{8}$ PP no 552007 Bab 2 Pasal 3

${ }^{9}$ Luthfi Khairul Fikri,et.al, Indonesian Journal of Islamic Education UPI, Vol. 2. No. 2, (2015): 178. 
perfection as a man of adab. It means a man with good adab has good behavior in interacting with others and their environment. ${ }^{10}$

Therefore, a well prepared of Islamic subject in school and higher education is necessary to fulfill religious education purposes. The main purpose of religious education is to enable students to obey their religion and make religion a platform to conduct ethics or morality in their personal and social life. The religious education subject embodies harmony, tolerance, respect among others for religious adherents as mentioned in the Government Regulation. ${ }^{11}$ The religious education subject if implemented appropriately can build peace education needs under its orders. The proper teaching and learning of religious education stimulate reducing conflicts and living together with other adherents in harmonious and friendship relationships.

Islam through qawliyyah verses of Al Quran and Al Hadith inspiring people with at least six stages in gaining an excellent society. The stages are ta'aruf (get to know other), tafahum (understand other), tadhamun (solidarity), tarahum ( loving), ta'awun (help each other), tasamuh (tolerance). Historically, the precept of Islam came to this world for establishing social justice and equality. At the time, an ignorant society was in place with many conflicts, injustice, discrimination, slavery rampant, domination one to another, no fairness, cheating, oppressive behaviors, and stupidity became a usual phenomenon in the Arabic peninsula.

\section{Simulation Based Learning in Religious Education for Tolerances}

Students' Tolerant attitudes can be expectedly achieved through a suitable and worthy learning method. In this study, the author proposes several stages that should be carried out by implementing simulation based learning in education with various games, role plays, and some other situated learning

\footnotetext{
${ }^{10}$ Aries Musnandar. (2016). Op.Cit. page. 64-74

${ }^{11} \mathrm{PP}$ no. 55 tahun $2007 \mathrm{Ch} 2$ article 5.
} 
resources. The following phases that may develop students' empathy toward an elevation of peace education program in schools are:

\section{Taaruf (Knowing Others)}

The meaning of ta'aruf is to know others. At the first games, students enter games of simulation on introduction each other. In the beginning, students know the names of their peers and then continue bit details in Tafahum level at the second step of understanding others.

2. Tafahum (Understanding Others)

Tafahum means to Therefore, these two words are inherent meaning. In the context of implementing ta'aruf a school teacher can conduct simulation on introduction games. Then, continued with tafahum games of simulation to raise awareness and increase understanding with other people who have different faith and distinctive values of respective religion adherent.

3. Tadhamun (Solidarity)

Well prepared games of simulation for getting Tadhamun level will be aimed to build solidarity. These games can increase the empathy of students and will build solidarity with others regardless of faith, origin, and background. Solidarity is the key to making real peace.

4. Tarahum (Loving)

After attending ta'aruf, tafahum, and tadhamun games of simulation, the teacher may create tarahum games. Muslim students who have a well understanding of Islamic precepts will admit and aware that the divinity in Islam is inseparably attached and connected with the human aspects. So, Muslim should understand Divinity in relating to humanity.

\section{Ta'awun (Helping Others)}

At this level, students will have the characteristics to help others by doing good deeds and always happy to assist people who need help regardless of their backgrounds either, gender, social status, or religion.

6. Tasamuh (Tolerance) 
After following previous games and practicing the empathy-based intra and inter-personal skills, students will expectedly reach the level of tasamuh which is the high level for students' manner or noble behavior. Respect other people who have different faith but students still interact in harmony, avoid conflicts, and always give help whoever people need it. Tasamuh attitude is the high level of interaction in human relationships to build tolerant character. At this level students always try to serve others first before themselves and avoiding bad manners such as hatred or obtrude manners.

7. Ta'ayus al Silmi (living together in harmony and peace)

Finally, the highest stage of peace education is people can live together with harmony and peace. It is certainly the processes stage 1 till 6 as mentioned above should be followed in proper and comprehensive ways. If attitudes on tolerance, respect, and altruism have been embedded in students' personalities, then the noble behavior will be a matter of time. Courtesy, politeness, and soft approach are always becoming engagement in students' human relationships.

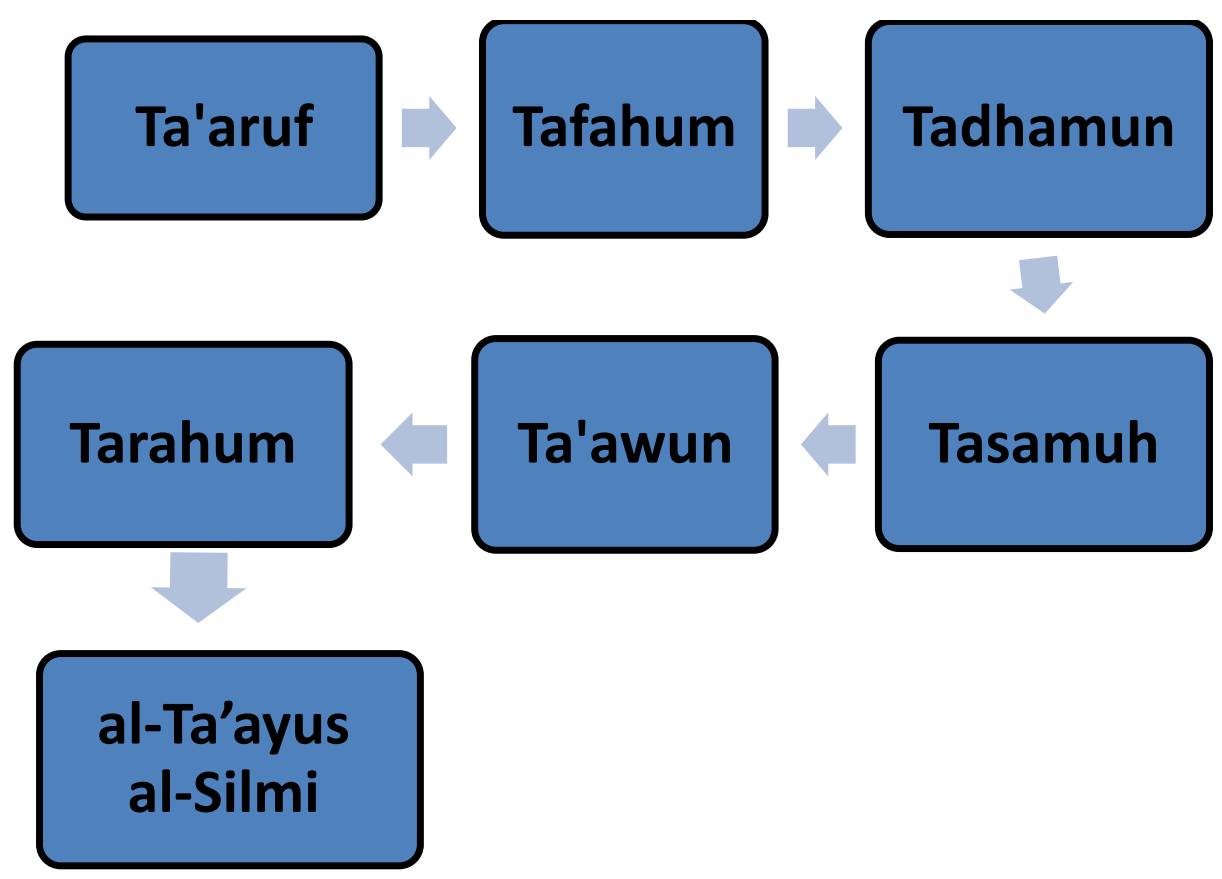

Picture 2

The Stages of Simulation-Based Learning Towards Peace Education 
Simulation practices with some role-play and games techniques is a learning model that focuses on the student as an active participant. These technics are convinced by education experts supported with research results will be able to increase students' care on values to be developed such as tolerance and togetherness. In developing such attitudes on students the role of the teacher becomes important because the teacher has the authority quite big to determine learning models. In accomplishing objectives, teachers should use various worthy methods of a variety of learning models. ${ }^{12}$

Noble Behaviour in Islamic Perspectives

Islamic teaching contains interrelated facets or an inseparable connection between ad-dunya and al-akhirah. This dunya life pertains to the life in the hereafter towards virtues and good for both in the world and the hereafter (addunya and al-akhirah) in happiness or success. Therefore, in Islam al-akhirah is the last destination for human life and will be the aim of every Muslim. The life of the hereafter is forever true life.

According to al-Attas, the dunya-in a profound and inseparable facet to the akhirah-aspect. Attention at the end on the akhirah-aspect without thereby implying any attitude of neglect or being unmindful of the dunya-facet. ${ }^{13}$ Allah's commandments about the good deeds, goodness, and righteousness towards a man of taqwa can be found in the following verses:

"It is not righteousness that ye turn your faces Towards east or West; but it is righteousness- to believe in Allah and the Last Day, and the Angels, and the Book, and the Messengers; to spend of your substance, out of love for Him, for your kin,

\footnotetext{
${ }^{12}$ Raka Joni \& Lusiana Djunaedi, “Pembelajaran Yang Mendidik.”, Learning Materials of Program Pascasarjana, (2005): 20-26

${ }^{13}$ al Attas \& Wan Daud, “The ICLIF Leadership Competency Model (LCM) An Islamic Alternative.", (2007): 7
} 
for orphans, for the needy, for the wayfarer, for those who ask, and for the ransom of slaves; to be steadfast in prayer, and practice regular charity; to fulfill the contracts which ye have made; and to be firm and patient, in pain (or suffering) and adversity, and throughout all periods of panic. Such are the people of truth, the Allah-fearing". ${ }^{14}$

"And seek help through patience and prayer, and indeed, it is difficult except for the humbly submissive [to Allah]". ${ }^{15}$

The Qur'anic verses above indicate that Muslims should enhance their grade of life aspect in dunya. The lesson point that we can obtain from the verses above is, that the God believers should improve their obeisance and character for the best degree of taqwa, or much more closer to the Almighty, Allah s.w.t. Reasonably, the piety man who has depth understanding of divinity would also reach excellent behavior and tolerant attitudes at once.

Additionally, the term taqwa is much deeper than piety, piousness, or and self-restraint. It combines plenty of facets, such as believing Allah as the only one God firmly, attention to the things that may someone closer to God, and being God-conscious. All righteous and good deeds are merely dedicated to Allah s.w.t.

The noble behavior unites by twining one with another that is the inner thought. The individuals' condition of Qolbun salim is a first required step for the great manner which is Islamic teaching. When an individual has qolbun Maridh (sick heart), his attitude may become worse causes a flesh heart. ${ }^{16}$

From an Islamic point of view, the empathy quality depending on the individuals condition of qolb or heart. As a Muslim, he/she is encouraged for the betterment of akhlaq (exemplary ethical-moral standing) in line with the

\footnotetext{
${ }^{14}$ Al Baqarah 2: 177.

${ }^{15}$ Al Baqarah 2: 45. Translated by Sahih International @ 2016 Quran.com.

${ }^{16}$ Aries Musnandar, (2016), Op.Cit. p. 55-56
} 
teachings of the Quran and Hadith. ${ }^{17}$ God Allah commands Rasulullah to meliorate human behaviors, to some extent, it could be interpreted as empathy enhancement. All Muslims in their daily life should implement and care to the orders of the Almighty and as people of faith, they must meet all of their obligations including to the surrounding environment, especially on how to build an excellent society with justice.

In Indonesia, Religious Education is admitted as one of the subjects delivered in schools and higher education, but it has not yet succeeded to present the real peace education that cultivates student empathy. This fact indicates that teaching and learning effectiveness on Religious Education subject is still low in affecting the quality level of students behavior and attitude.

\section{Empathy Development on Peace Education}

Personal empathy can be developed through various training by showing off expressions and non-verbal communications that make other people feel accepted and understandable. The empathy ability involves the capabilities to comprehend other individuals feeling based on the understanding of non-verbal signs of other people. This perceives can maintain good human relations in accord with empathetic behaviors. Eventually, religious education as a mandatory subject in public schools and higher education institutions should be implemented this simulation-based learning method to enhance empathy for obtaining desired peace education outcomes.

Besides, simulation-based learning method in class needs follows up actions or practice in the daily situation. Hence, visiting programs to other communities and people who have different, and distinctive backgrounds in terms of faith, culture, gender, ethnic and social status are encouragingly held.

\footnotetext{
${ }^{17}$ Aries Musnandar, (2016), Op.Cit. p. 56-57
} 
The teacher prepares such programs and she/he can bring the results into class on the next review session.

Individuals who demonstrated intolerant and violent actions usually because of their stereotype of others are bias and prejudice, so they will behave in improper manners when interacting with people. The condition mentioned above can happen due to less quality of personal empathy. Therefore, an empathy development program is necessary to be conducted in public schools and higher education institutions too.

Peace education is an effort to overcome conflicts, violence, obtrude, insults, and feud either in the national, regional, and global scales up to local and personal scopes. The orientation of peace education is to create a better future and sustainable life in a respectful climate. Peace education should have education inputs that possess mission and potential peace, then it is intended can create harmony and serenity.

Peace education relates to the process of acquiring values, knowledge, and improving attitudes, skills character, and behavior for living in harmony with others, with oneself, and with the natural environment. In an education context, it is essentially elevating the knowledge, skills, attitudes, and values required for the behavior of learners or students to constantly be able to soak peaceful conflicts, and then avoid conflict and violence in the environment. The crucial role of teachers in peacebuilding because teachers are key agents in the educational process. Teachers in class can promote social cohesion and peace, address the legacy of social conflict in contexts where ethnicity, race, and religion have to lessen against social cohesion.

Peace education is activities towards promoting knowledge, skills and helping others that either prevent society from conflicts with a conflict resolution or create social and conducive conditions for peace. It is a concept that delineated values of gender, religion, culture, ages, physical appearance, unity, and fairness. Overcoming conflict without violence, educating students to respect multi-cultural diversity can be a priority in schools' peace education 
programs. Thence, the aforementioned programs can make students respect and involve in social activity enthusiastically.

Epilog

The concept of learning evaluation the assessment for the cognitive domain is quite different from the affective domain. The first one is to measure the intellectual capacity awhile, the second one is the assessment-related affective moral, ethical, and noble human values. Based on the predetermined education goals, students should have these cognitive and affective capabilities across subjects delivered by the teacher. The academic ability can be measured at least through the various paper and pencil tests, The affective domain is very typical, must be observed, and cannot be measured through a written test alone, because it is visible (moral action).

Indeed, gaining the tolerant attitudes of students need to implement the right and appropriate evaluation. The use of paper and pencil tests for evaluating the affective side of students are wrong tasks despite generally happen in most schools. ${ }^{18}$ The habituation programs should be in place for students to elevate their good behavior after they understand the values of good behavior through simulation based learning in religious education.

Eventually, students need to be encouraged for absorbing the philosophy of life on the right path. Individuals' success is derived from individual character. ${ }^{19}$ There are two parts of caring individuals empathy and need to be conducted inherently as follows:

a. Internalization of knowing, feeling, loving, and acting is important in every subject matter for directing students to behave appropriately towards others. Therefore, such attributes should be pervasive in their insights. ${ }^{20}$

\footnotetext{
${ }^{18}$ Musnandar. Op.Cit (2016). Page 2-4

${ }^{19}$ James K, The "Soft Skills" of Success, Wellington: New Your: Aug 1, Vol. 71, No. 20 (2005):

${ }^{20}$ Ratna and Wahyu, Farrah, Seri Pendidikan Karakter. (I HF, 2011), P. 30
} 
b. Training and development programs for teachers' understanding of the need for empathy are necessary, important, and urgent to create teachers who are liked and loved by students whereas teachers will also certainly love and like their students. ${ }^{21}$

Religious education is mandatory for all schools and higher education students based on their respective religions. In the Islamic religion subject, there is a topic called Akhlak or can be interpreted popularly as human moral as well as human ethics but from Islamic perspectives. Yet, the achievement learning results of the said topic has not performed a significant result. Likely, it has not succeeded to perform students' daily noble behavior as ordered by the Islamic teachings. Consequently, bad deeds like intolerance, obtrude and violence to others still happens and tends to increase from time to time either in quantitative or qualitative, not vice versa.

Individuals who have reprehensible behavior or disgraceful character can make discomfort and social problem. Rough acts and bad behaviors of students in the public sphere such as bullying, juvenile delinquency, a street brawl, and vandalism are caused by their qolbun maridh (the heart is sick). Plenty of schools only prefer to improve students' intellectual skills rather than students' soft skills. Unfortunately, this condition makes the phenomena above often appeared in public areas.

One of the most crucial stages of nurturing our kids is to have the appropriate school education. According to the Prophet tradition, the best legacy that parents can give to their young generation is proper didactics that may advantage for them to live as a good man not only good citizen. As a good man, he will perform well for this world life and obedience to the commands of Allah for preparation in the hereafter life. The Prophet (PBUH) said, "The best gift to children from parents is their correct education". ${ }^{22}$ The parents have heavy tasks and responsibilities for their children since the early childhood period to make

\footnotetext{
${ }^{21}$ Aries Musnandar (2016): p. 139

${ }^{22}$ Hadist by Tirmizi
} 
them would love and obey the one God, Allah s.w.t., His Prophets, and the Islamic teachings.

Ulema or Islamic scholar classify Islam into four parts, namely aqidah, ibadat, mua'malat, and akhlaq. Ibadat are rituals. Muamalat is figh, a set of Islamic law inherent with human relations such as doing business, marriage, etc. Moslems should conduct Akhlaq well in living harmony in this society. Whereas, Akhlaq-al kareem is referred to as the best behavior for practicing Islamic values.

\section{Conclusion}

The peace education programs in Indonesian schools can be elevated through religious education subjects, but schools need to review their learning and teaching approach as proposed by the author. This study discourses on the teaching and learning methods to succeed in getting noble behavior performed by students. In this thing, empathy attribute is a determining factor to have such noble behavior including for shaping tolerant attitudes of students. Indonesian schools implement and or deliver a religious education as a mandatory subject for students to have.

School students and a higher level of education including university students in Indonesia must take religious subjects based on their respective religions. Despite in religious subject there is a lesson about akhlak (morals or ethics) to be delivered by teachers but, unfortunately, the implementation results still far away from desirable objectives. This situation is likely due to a lot of teachers do not use creative and appropriate methods for students in applying religious subject to peace education

Theoretically, a simulation based learning method can be used for improving expected students behavior in peace education by fostering the capacity of student empathy. The peace education program in religious subjects can be elaborated by using simulation based learning to develop students' empathy. At present, due to improper methods used in a religious subject, the 
learning students' outcome can not be achieved optimally. This indicates the effectiveness of teaching and learning on Religious Education has not yet significantly affected the students' behavior quality.

In contrast, the simulation based learning model for religious education could involve the affective domain which is appropriate to be used for behavior change. This study proposes an effective learning model to increase the quality of students' empathy through simulation-based learning. This model is considered proper and in line with the objectives of religious education to shape a student's noble behavior by fostering empathy. It confirms from this study that peace education can be achieved through religious education subjects in schools when teachers implement a suitable method of behavior change that is a simulation based learning approach.

\section{References}

Al Attas, Naquibb \& Wan Daud, Wan Mohd Nor. 2007. The ICLIF Leadership Competency Model (LCM): An Islamic Alternative. ICLIF. KL. Malaysia.

Endin Mujahidin, et.al., (2012). Developing Character Education Quality in Elementary School. Paper presented at the International Conference UIN Malang, December 2-3, 2012.

Given, Lisa M (ed.) The Sage Encyclopedia of Qualitative Resarch Methods. Vol 1 \& 2. USA: SAGE Publications, 2008.

Megawangi, Ratna et al. (2011). Neuroscience for Kids: Pengendalian Emosi Anak. Seri Pendidikan Karakter. Depok. Indonesia Heritage Foundation.

Megawangi, Ratna et al. (2011). Membangun Karakter Anak melalui Brain-Based Parenting (Pola Asuh Ramah Otak). Seri Pendidikan Karakter. Depok. Indonesia Heritage Foundation.

Megawangi, Ratna and Farrah, D., Wahyu. (2011). Sekolah Berbahaya bagi Perkembangan Karakter Anak: Solusi untuk Mempersiapkan Sekolah dalam Menjalankan Pendidikan Karakter. Seri Pendidikan Karakter. Depok. Indonesia Heritage Foundation.

Musnandar, Aries. 2014. Indonesia: A Country of Challenge. Malang. UB Press. Musnandar, Aries. 2013. Pendidikan yang Mencerdaskan. Malang. Naila Pustaka 
Raka Joni, T \& Djunaedi, Lusiana. 2005. Pembelajaran Yang Mendidik: Artikulasi Konseptual, Terapan Kontekstual dan Verifikasi Empirik. PPs, Universitas Negeri Malang.

Sternberg, R. (2000). Handbook of Intelligence. Cambridge, UK: Cambridge : University Press.p. 396-417

Republik Indonesia. Undang-Undang Nomor 20 Tahun 2003 tentang Sistem Pendidikan Nasional.

Peraturan Pemerintah RI Nomor 17 Tahun 2010 tentang Pengelolaan dan Penyelenggaraan Pendidikan

Peraturan Pemerintah RI No. 55 Tahun 2007 Bab 2 Pasal 3 tentang Pendidikan Agama

European Journal of Scientific Research ISSN 1450-216X Vol. 91 No 1 November, 2012, p.69 @ EuroJournals Publishing, Inc. 2012

Budiarti, Tirsa.(2018). Model-Model Pendidikan Perdamaian Bagi Anak Dalam Konteks Gereja, Jurnal Jaffray, Vo. 16, No. 1 (April 2018). Page 67-69.

Fikri, Khairul Luthfi, et.al. Perkembangan Pendidikan Agama Islam Di Sekolah Dasar Tahun 1945-1966. Tarbawiy. Indonesia Journal of Islamic Education. UPI. 2015. Vol. 2 No. 2, page 178.

Wellington, James (2005). The Soft skills of Success. Vital Speeches of the Day, August 1, vol 71, Iss. .20, pg. 628. 7 pgs

Musnandar, Aries. The Instructional Management of Students Soft Skills In Elementary Schools: A Multi-Case Study at Sekolah Karakter Indonesia Heritage Foundation (IHF) and Sekolah Dasar Brawijaya Smart School (BSS). Dissertation, Maulana Malik Ibrahim, State Islamic University, 2016.

Musnandar, Aries. Keefektifan Pembelajaran Soft Skills Sebagai Faktor Keberhasilan Unjuk Kerja Mahasiswa yang diperlukan dunia usaha dan industry. Proposal Disertasi, Psikologi Pendidikan Program Pascasarjana Universitas, Negeri Malang, 2006.

Musnandar, Aries. Pengembangan Paket Pembelajaran Presentation Skills bagi Karyawan Penyelia PT. Philip Morris Indonesia, Thesis Teknologi Pembelajaran, Program Pascasarjana UM, 2004.

Aries Musnandar, Taking examples of Prophet's tolerance. the Jakarta Post, February 7, 2012

A. Chaedar Alwasilah, Holistic education creates 'perfect people'. the Jakarta Post, $01 / 28 / 2012$

Lajnah Pentashihan Mushaf Al Quran Badan Litbang dan Diklat. Tafsir Al Quran Tematik: Spiritualitas Dan Akhlak, Kementerian Agama, 2010 